\title{
IMPROVING CUSTOMER LOYALTY THROUGH EXPERIENTAL VALUE, SERVICE QUALITY AND TRUST
}

\author{
Rifki Arikah An Namla, Sukaris, Budiyono Pristyadi, Al Kusani \\ Management, Faculty of Economics and Business, Universitas Muhammadiyah Gresik \\ Gresik
}

\author{
Author Correspondence: \\ Sukaris \\ Sukaris21@umg.ac.id
}

\begin{abstract}
ABSTRAK
Pelanggan dengan loyalitas yang tinggi merupakan aset perusahaan karena mereka akan memberikan rekomendasi yang positif dan secara tidak langsung akan mengajak masyarakat sekitar untuk menentukan dan menggunakan produk jasa perusahaan yang mereka gunakan. Penelitian ini bertujuan untuk mengetahui apakah terdapat pengaruh nilai pengalaman, kualitas pelayanan dan kepercayaan terhadap loyalitas pelanggan indihome di Kabupaten Gresik. Pengambilan sampel menggunakan Non Probability Sampling dengan menggunakan rumus Ferdinand, dimana jumlah sampel adalah 100 orang. Analisis yang digunakan dalam penelitian ini adalah regresi linier berganda. Hasil penelitian terbukti menunjukkan bahwa nilai pengalaman, kualitas pelayanan dan kepercayaan berpengaruh positif dan signifikan terhadap loyalitas pelanggan di Kabupaten Gresik.
\end{abstract}

Kata Kunci: Nilai Pengalaman, Kualitas Layanan, Kepercayaan, dan Loyalitas Pelanggan

\begin{abstract}
Customer with high loyalty are the assets of the company because they will provide positive recommendations and indirectly will invite people around to determine and use the product of the service company they use. This research aims to find out whether there is an effect of experiential value, service quality and trust on customer loyalty indihome in Gresik regency. Sampling is used Non Probability Sampling by using Ferdinand formula, where the sample amount is 100 people. The analysis used in this study is multiple linear regressions. The results are proven to show that experiential value, service quality and trust have a positive and significant effect on customer loyalty in Gresik regency.
\end{abstract}

Keywords: Experiental Value, Service Quality, Trust, and Customer Loyalty

\section{INTRODUCTION}

The development of technology, information and communication is currently so fast, because it has become a primary need of society and has a large enough impact on various human aspects, especially internet technology. Internet is a communication that is done globally and interactive, in addition, the internet also provides information and services that enable opening new markets, products or services, and integrating online activities.

In the last decade, the development of information technology has undergone substantive changes in shaping consumer behavior. With the internet, opportunities for consumers to make purchases become wider through various access to products / services and increase the ease of making purchases as stated by Sukaris et al., (2019) that technological advances through various media platforms both print, electronic, digital media and social media contributes to shifting consumer consumption patterns . One form of business and marketing activities that apply the concepts of electronic markets, digital marketing, and e-commerce which are currently prevalent is the online store business ((Hartini et al., 2020), 
Indo nesia Digital Home (abbreviated as IndiHome ) is one of the service products from PT Telekomunikasi Indonesia in the form of communication and data service packages such as landlines (voice), internet (Internet on Fiber or High Speed Internet), and interactive television services (USee TV Cable, IP TV), because of this offer Telkom labeled indihome as three services in one package ( 3 in 1 ) because apart from the internet, customers also get pay $\mathrm{TV}$ and telephone lines. Data on Indihome service users in Gresik Regency is in accordance with Figure 1.1 as follows:

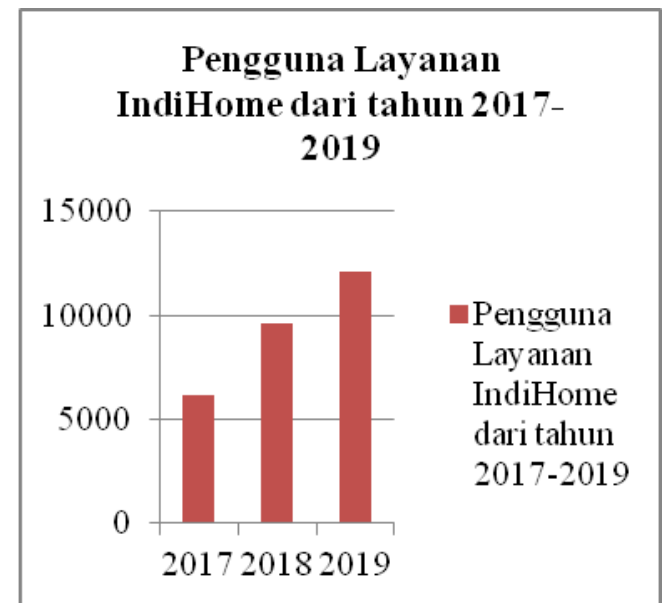

Source: Authors'

compiled data from the official website of PT Telkom

\section{Figure 1:Telkom Gresik Regional Indihome Service Users in 2017-2019}

Figure 1 shows that the increase in users of i ndihome services in Gresik district has always increased from 2017 to the end of 2019. This increase has made companies currently use new strategies to attract more consumers and retain old users.

According to Kotler and Keller (in Yelli, 2017: 8) suggesting that loyalty is a deeply held commitment to buy or support a preferred product or service in the future even though it affects the situation and marketing efforts make customers switch. Based on the description above, the researchers are interested in conducting research on "The Effect Experiental Value, Service Quality and Trust Of Customer Loyalty Indihome in Gresik".

\section{LITERATURE REVIEW Experiental Value}

Experience is a medium that makes consumers feel that they have a mental, physical, emotional attachment to using a product or service. Experiential Value is the perception that customers receive for product attributes or service performance resulting from interactions when using products or services so as to provide facilities or hinder the intent of customer goals, Holbrook et al (in Khadi jah, 2019: 16) . Experiential Value is also a customer's view of a product or service through direct use or indirect observation.

Perceived values aim to strengthen the benefits that can be obtained or obtained by the buyer for the costs incurred compared to the benefits that will be obtained from purchasing other products . Therefore, it can provide a strong impetus for purchasing decisions, recommendations to others, and positive WOM (Sukaris, et al., 2020).

\section{Service Quality}

According to Kotler (2009: 143) which uses the definition of American Society for Quality Control: Quality is a totality of features and characteristics in a product or service that depends on its ability to make a sense of satisfaction in every need which is basically stated or implied. Meanwhile, according to Tjiptono (2011: 157) service is an activity that cannot have a separate definition and indeed, basically, service quality has an intangible nature, so that it meets needs and does not always have an attachment to product sales or other sales. Service Quality can also be interpreted as a measure of how well the level of service provided in each company is in accordance with customer expectations.

\section{Trust}

Trust is someone's desire to rely on other people in whom we have confidence. According to Garbarino Janson (in Eko Saputra, 2017: 93) suggests that the notion of trust in service marketing emphasizes individual attitudes which refer to consumer confidence in the quality and constraints of the services they receive. Meanwhile, according to Rousseau (In Trisusanti, 2017: 7) trust is a psychological area which is a concern for 
accepting what it is based on expectations of good behavior from others.

Consumer trust is defined as the willingness of one party to accept the risk from the actions of the other party to take important actions for the party who trusts it, regardless of the ability to supervise and control the actions of the trusted party. According to Sunarto (in Saputra, 2017: 93) consumer trust is all knowledge possessed by consumers and all conclusions made by consumers about objects, attributes and benefits.

\section{Customer Loyalty}

According to Griffin (in Trisusanti, 2017: 8) states that "loyalty is defined as non random purchase expressed over time by some decision making unit" that loyalty refers more to decision-making units to make continuous purchases of goods or services from companies that have been selected. Meanwhile, according to Oliver (in Keller, 2009: 138) Loyalty is a deeply held commitment to buy or support back preferred products and services in the future even though the influence of the situation and marketing efforts have the potential to cause customers to switch .

\section{Experiential}

\section{Value Relationship with Customer Loyalty}

Customer loyalty can be said when customers have a positive experience with a product or service, especially on the value of the experience they have. Customer loyalty is not formed in a short time, but through a learning process and based on the experience of consumers themselves from consistent purchases over time. If what is obtained is in accordance with expectations, then this buying process will continue to be repeated. According to Holbrook et al (in Khadija, et al. 2019: 16) Experiential Value is something that is relatively accepted by customers for product attributes or service performance resulting from interactions when consuming or using products or services so that it can facilitate or hinder the achievement of goals and objectives. customer. As in the research of Khadijah, Rahmah and Renjana (2019), they say that Experiential Value has a positive effect on Customer Loyalty. So this shows that the relationship between experiential value and customer loyalty is positive.

\section{Relationship between Service Quality and Customer Loyalty}

A Quality of Service will greatly affect Customer Loyalty, if the quality of service from the company provides the best and makes customers satisfied then loyal consumers are created. As stated by Kotler (in Trisusanti, 2017: 3) Quality of service can encourage customer visits at the next opportunity at the business entity concerned. The results of research conducted by Trisusanti (2017) say that Service Quality has a significant effect on customer loyalty. So this shows the relationship between service quality and customer loyalty is positive.

\section{Trust Relationship to Customer Loyalty}

Consumer trust in a product or service and company credibility is one of the factors that makes consumers loyal to a company. Trust is also a mental condition based on a person's situation and social context (Putra: 2017). As the results of research from Trisusanti (2017). stated that trust has a significant effect on customer loyalty.

\section{Hypothesis}

1. There is an influence of Experiental Value on IndiHome Customer

Loyalty in Gresik Regency .

2. There is an effect of Quality Serv ice on IndiHome Customer Loyalty in Gresik Regency .

3. There is the influence of $T$ rust on Customer Loyalty IndiHome in Gresik .

\section{METHODE}

This type of research used in this research is a quantitative approach. According to Sugiyono (2017: 8) Quantitative research is a research method based on the philosophy of positivism, used to research on certain populations or samples, data collection using research instruments, data analysis is quantutative or statistical, with the aim of testing predetermined hypotheses.

\section{Population and Sample}

According to Sugiyono (2017: 80) Population is a generalization area consisting of objects / subjects that have certain qualities and characteristics that are determined by 
researchers to study and then draw conclusions. The population in this study are all people who subscribe to Indihome in Gresik district .

In this study, the sampling technique used a non-probability sampling method. Nonprobability sampling is a sampling technique that does not provide equal opportunities / opportunities for each element or member of the population to be selected as samples (Sugiyono, 2017: 84). The sample is part of the number and characteristics possessed by the population, or a small part of the population members taken according to certain procedures so that it can represent the population. The sample size in this study is determined using the formula from Ferdinand (2014: 94):

$\mathrm{n}=(25 \times$ independent variable $)=25 \times 3$ independent variable $=75$ samples

The sample of mini mall that can be taken is 75 Indihome customers. However, to simplify the research process both in determining the validity of the data and in calculating the analysis, the researchers determined 100 respondents.

\section{Data collection technique}

In this study using a questionnaire. According to Sugiyono (2017: 137) questionnaire, namely a data collection technique that is carried out by asking questions that have been prepared in writing by distributing questionnaires and accompanied

Tabel 1: Validity Test Results by alternative answers to be given to respondents. Data obtained from the results of the questionnaire answers from respondents who have received questionnaires that have been distributed. The respondents referred to here are Indihome customers who still use Indihome services in Gresik Regency.

In order for the research to be more efficient in obtaining data from respondents, the researchers used the questionnaire method. The questionnaire was prepared using five alternative answers, namely SS (strongly agree), S (agree), N (neutral), TS (disagree), STS (strongly disagree).

\section{RESULTS \\ Instrument Test}

The instrument test was carried out to determine whether the instrument that was prepared was a good result, because the good or bad of the instrument would affect the accuracy of the data and determine the quality of the research results. The following are the results of the validity and reliability tests:

\section{Validity test}

In this case the researcher uses SPSS to process the data contained in the questionnaire about the validity test. The results of the processed data are as follows:

\begin{tabular}{|c|c|c|c|c|c|}
\hline No. & Statement Item & $\begin{array}{l}\mathrm{R} \\
\text { Count }\end{array}$ & $\begin{array}{l}\mathrm{R} \\
\text { Table }\end{array}$ & Sig & Information \\
\hline \multirow[t]{7}{*}{1.} & $\mathrm{X} 1$ & & & & \\
\hline & $\mathrm{X} 1.1$ & 0.781 & 0.1966 & 0,000 & Valid \\
\hline & $\mathrm{X} 1.2$ & 0.770 & 0.1966 & 0,000 & Valid \\
\hline & $\mathrm{X} 1.3$ & 0.738 & 0.1966 & 0,000 & Valid \\
\hline & $\mathrm{X} 1.4$ & 0.721 & 0.1966 & 0,000 & Valid \\
\hline & $\mathrm{X} 1.5$ & 0.808 & 0.1966 & 0,000 & Valid \\
\hline & $\mathrm{X} 1.6$ & 0.770 & 0.1966 & 0,000 & Valid \\
\hline \multirow[t]{12}{*}{2 , } & $\mathrm{X} 2$ & & & & \\
\hline & $\mathrm{X} 2.1$ & 0.677 & 0.1966 & 0,000 & Valid \\
\hline & $\mathrm{X} 2.2$ & 0.558 & 0.1966 & 0,000 & Valid \\
\hline & $\mathrm{X} 2.3$ & 0.621 & 0.1966 & 0,000 & Valid \\
\hline & $\mathrm{X} 2.4$ & 0.736 & 0.1966 & 0,000 & Valid \\
\hline & $\mathrm{X} 2.5$ & 0.496 & 0.1966 & 0,000 & Valid \\
\hline & $\mathrm{X} 2.6$ & 0.649 & 0.1966 & 0,000 & Valid \\
\hline & $\mathrm{X} 2.7$ & 0.667 & 0.1966 & 0,000 & Valid \\
\hline & $\mathrm{X} 2.8$ & 0.746 & 0.1966 & 0,000 & Valid \\
\hline & X2.9 & 0.629 & 0.1966 & 0,000 & Valid \\
\hline & $\mathrm{X} 2.10$ & 0.690 & 0.1966 & 0,000 & Valid \\
\hline & $\mathrm{X} 2.11$ & 0.573 & 0.1966 & 0,000 & Valid \\
\hline \multirow[t]{2}{*}{3.} & X3 & & & & \\
\hline & $\mathrm{X} 3.1$ & 0.707 & 0.1966 & 0,000 & Valid \\
\hline
\end{tabular}




\begin{tabular}{cccccc}
\hline & X3.2 & 0.791 & 0.1966 & 0,000 & Valid \\
\hline X3.3 & 0.703 & 0.1966 & 0,000 & Valid \\
\hline X3.4 & 0.773 & 0.1966 & 0,000 & Valid \\
\hline X3.5 & 0.825 & 0.1966 & 0,000 & Valid \\
\hline 4. & 0.755 & 0.1966 & 0,000 & Valid \\
\hline & & & & \\
\hline & Y & 0.833 & 0.1966 & 0,000 & Valid \\
\hline Y1 & 0.802 & 0.1966 & 0,000 & Valid \\
\hline & Y2 & 0.794 & 0.1966 & 0,000 & Valid
\end{tabular}

From the results obtained in the questionnaire validity test all variables obtained $r$ count $r$ table 0.1966 . So that all statement items / indicators from the independent and dependent variables are proven valid and capable of explaining the independent and dependent variables.

\section{Reliability Test}

Reliability is said to be reliable if it has a Cronbach's Alpha value > 0.60 (Sugiono, 2015 ; 184). Based on calculations performed with SPSS, reliability testing in this study are shown in Table 2 below:

Table 2: Reliability Test Results

\begin{tabular}{lllll}
\hline No. & Item & Cronbach Alpha & Critical Value & Information \\
\hline 1 & Experiantal Value & 0.857 & 0.70 & Reliable \\
\hline 2 & Service Quality & 0.852 & 0.70 & Reliable \\
\hline 3 & Trust & 0.849 & 0.70 & Reliable \\
\hline 4 & Customer Loyalty & 0.734 & 0.70 & Reliable \\
\hline
\end{tabular}

Based on the table of results from the reliability test, it can be explained that the value of Cornbach Alpha is 0.70 , so all of the items in the statement all the variables in the trend can be declared reliable or reliable.

\section{Classic Assumption Test Normality test}

In a study, the Normality Test aims to test whether the data has a normal or abnormal distribution. Whereas in this study using Kolmogorov Smirnov's non-parametric analysis, the selection of this analysis can minimize the occurrence of errors when compared with graphic analysis. In the normality test, it can be said to be normal if the significant value is 0.05 .

\section{Multicollinearity Test}

Based on calculations performed with SPSS, testing multicolinearity in this study is shown in Table 3: the following:

Table 3 Multicollinearity Test Results

\begin{tabular}{llll}
\hline Variable & Tolerance Value & VIF & Information \\
\hline Experiental Value $(X 1)$ & 0.496 & 2.017 & Nonmulticollinearity \\
\hline Service Quality $(X 2)$ & 0.878 & 1,140 & Nonmulticollinearity \\
\hline Trust $(X 3)$ & 0.478 & 2,091 & Nonmulticollinearity \\
\hline
\end{tabular}

From the table above, the results of the multicollinearity test can be obtained that the Tolerance Value is greater than 0.10 or equal to the VIF value less than 10 . It can be concluded that the regression model shows that multicollinearity does not occur.

\section{Heteroscedasticity Test}

In a heteroscedasticity test study aims to test whether in the regression model there is an inequality of the variance of the residuals from one observation to another. If the results are 
the same, it can be called homoscedasticity, but if the results are different, it is called heteroscedasticity. The test used in this study used the Spearman correlation test. On the Table 4: Test Results heterokedastisitas

\begin{tabular}{lll}
\hline Variable & Sig & Information \\
\hline Experiental Value $(X 1)$ & 0.109 & Heteroscedasticity does not occur \\
\hline Service Quality $(X 2)$ & 0.709 & Heteroscedasticity does not occur \\
\hline Trust $(X 3)$ & 0.710 & Heteroscedasticity does not occur \\
\hline
\end{tabular}

Based on the above results, it shows that the results of the Spearman correlation test, Experiential Value (X1) 0.109, Service Quality (X2) 0.709. Trust (X3) 0.710, it can be basis of decision making, if sig 2-failed 0.05, heteroscedasticity occurs and a if sig 2failed 0.05 , heteroscedasticity does not occur.

Table 5: Multiple Linear Regression Test Results

\begin{tabular}{llllll}
\hline & \multicolumn{2}{l}{ Unstandardized Coefficients } & \multicolumn{2}{l}{$\begin{array}{l}\text { Standardized } \\
\text { Coefficients }\end{array}$} & \\
\cline { 2 - 4 } Model & $\mathrm{B}$ & Std. Error & Beta & t & Sig. \\
\hline 1 (Constant) & 1,784 & 1,340 & & 1,332 & .186 \\
\hline Experiental Value & .136 & .060 & .266 & 2,255 & .026 \\
\hline Service Quality & .065 & .032 & .181 & 2,046 & .044 \\
\hline Trust & .136 & .061 & .268 & 2,236 & .028 \\
\hline
\end{tabular}

a. Dependent Variable: $\mathrm{y}$

In the multiple linear regression equation above, it can be concluded as follows:

1. Constant Value $=1.784$

Based on the linear regression equation which can show that if the variable experiential marketing, service quality, and trust has a value of 0 or there is no change, then the customer loyalty indihome in Gresik Regency is 1.784 which means that the $\mathrm{Y}$ variable is needed.

2. Regression coefficient for $\mathrm{X} 1=0.136$ Based on the linear regression equation obtained, it shows that the coefficient is positive, so the better the Experiential Marketing of indihome customers in Gresik Regency, the higher the Indihome Customer Loyalty in Gresik Regency. concluded that heteroscedasticity does not occur.

\section{Multiple Linear Regression Analysis}

Tests carried out with the help of SPSS obtained the following results: 
determination can be seen in the table as follows:

Table 6: Test Results of the Coefficient of

\begin{tabular}{|l|r|r|r|r|}
\hline Model & \multicolumn{1}{|c|}{$\mathrm{R}$} & $\mathrm{R}$ Square & $\begin{array}{c}\text { Adjusted } \\
\text { R Square }\end{array}$ & $\begin{array}{c}\text { Std. Error of } \\
\text { the Estimate }\end{array}$ \\
\hline 1 & $.582^{\mathrm{a}}$ & .338 & .318 & 2.15293 \\
\hline
\end{tabular}

a. Predictors: (Constant), $\times 3, \times 2, \times 1$

b. Dependent Variable: $y$

Determination

Based on the results of the coefficient of determination, it is known that the Adjusted Hypothesis Testing

T test (partial)

Table 7: Partial Coefficient Test Results (t test)

\begin{tabular}{llllll}
\hline \multirow{2}{*}{ Model } & \multicolumn{2}{l}{ Unstandardized Coefficients } & \multicolumn{2}{l}{$\begin{array}{l}\text { Standardized } \\
\text { Coefficients }\end{array}$} & \\
\cline { 2 - 4 } & $\mathrm{B}$ & Std. Error & Beta & 1,332 & Sig. \\
\hline 1 (Constant) & 1,784 & 1,340 & & 2,255 & .026 \\
\hline Experiental Value & .136 & .060 & .266 & 2,046 & .044 \\
\hline Service Quality & .065 & .032 & .181 & 2,236 & .028 \\
\hline Trust & .136 & .061 & .268 & & \\
\hline
\end{tabular}

$R$ Square value can be said that the change in the dependent variable Customer Loyalty $(\mathrm{Y})$ is 0.318 or $31.8 \%$ by the Experiental Value (X1), Service Quality (X2), and Trust (X3) variables . whereas it can be explained by other factors outside of these variables, namely $68.2 \%$. Due to the fact that there are several statements given by the respondent, they are doubtful, so the coefficient of determination is known that the Adjusted $R$ Square value shows $31.8 \%$.

\section{b. Dependent Variable: $y$}

1. Based on the table listed above, it shows that the experiential significance value is $0.026 / 0.05$, so it can be said that $\mathrm{HO}$ is rejected and $\mathrm{H} 1$ is accepted. Then there is an influence between the experiental value variable on customer loyalty.

2. Based on the table listed above, it shows that the significance of service quality is $0.044 / 0.05$, it can be said that $\mathrm{HO}$ is rejected and $\mathrm{H} 1$ is accepted. Then there is a variable effect of service quality on customer loyalty.

3. Based on the table listed above, it shows that the significance of trust is $0.028 / 0.05$, it can be said that $\mathrm{H} 0$ is rejected and $\mathrm{H} 1$ is accepted. Then there is an influence between the trust variable on customer loyalty.

\section{DISCUSSION}

Influence Experiental

(X1) To Customer Loyalty (Y)

The results of the study show that the experiential value (X1) variable has a positive and significant effect on customer loyalty $(Y)$. Positive results mean that the stronger the experiential value (X1) of indihome, the higher the customer loyalty . Indihome can attract the hearts of customers because it has a strong enough value Experiential value is a perception or view that can be accepted by customers on product attributes or performance of a service that results from interactions when using a product or service so as to provide facilities or hinder the desire of customers to use the product or service. other services (Holbrook et al, in Ayu Khadijah, et al: 2019). 
While the significant results illustrate that the experiential value variable (XI) is able to be a determining factor in influencing customer loyalty $(Y)$. in this case it is in accordance with the results of previous research, namely Khadijah, Rahmah, and Renjana (2019) with Experiential value which can have a significant effect on customer loyalty.

The value experience that each customer has in using indihome services is quite good. In terms of service, the equipment used to install the indihome service network, as well as the knowledge possessed by officers really make customers feel satisfied so that they feel loyal to indihome services.

\section{Effect of Service Quality (X2) on Service Quality (Y)}

The results of the study indicate that the service quality variable $(X 2)$ has a positive and significant effect on customer loyalty $(Y)$. positive results mean that the stronger the service quality (X2) of indihome, the higher the customer loyalty. Where is the service from customer service that makes customers have a good perception of indihome. Service quality according to Keller (2009) is a feature and characteristic in a product or service that depends on every capability the company has and makes a sense of satisfaction in every customer need.

While the significant results illustrate that the service quality variable $(X 2)$ is able to be a determining factor in influencing customer loyalty $(Y)$. in this case it is in accordance with the results of previous research by Trisusanti (2017) which states that service quality has a significant effect on customer loyalty.

The services provided by Customer Service are in accordance with what customers expect, from the timeliness provided by the customer service when providing services. And when handling complaints given by customers within a certain time.

\section{The Effect of Trust (X3) on Customer Loyalty} (Y)

The results of the study show that trust (X3) has a positive and significant effect on customer loyalty $(Y)$. a positive result means that the stronger the trust (X3) of the indihome, the higher the customer loyalty. Which indihome has its own trust from customers who have used the service for a long time. According to Janson (in Saputra: 2017), trust is an individual attitude that refers to the belief of every consumer in the quality and constraints of the services they receive.

While the significant results illustrate that the trust variable $(X 3)$ can be a determining factor in influencing customer loyalty $(Y)$. in this case it is in accordance with the results of Putra's previous research (2018) which states that trust has a significant effect on customer loyalty.

PT Telkom provides an indihome service product with various service features that can be accessed by customers with certain advantages, providing guarantees on what customers have purchased or used when using indihome services. Giving high trust to every customer.

\section{CONCLUSIONS}

Based on the tests and analyzes that have been obtained by researchers as follows: Experiential value variable has a positive and significant effect on customer loyalty indihome in Gresik Regency. Service quality variable has a positive and significant effect on customer loyalty indihome in Gresik Regency. Trust variable has a positive and significant effect on customer loyalty indihome in Gresik Regency.

Based on the results of the analysis, discussion and conclusions of this study, the recommendations of the research can be given as follows: For Managerial Aspects: As a company engaged and developing in the telecommunications and information sector, it must be able to have loyal customers in order to increase the company's margins with several 
more sophisticated strategies. That way PT Telkom can compete with other competitors who are also engaged in the same field. For this reason, it can improve several factors that can affect customer loyalty, including: Experiental Value, Indihome is expected to be able to give customers the perception that the service products used have high comfort and satisfaction. Can by providing a much better service in accordance with customer expectations so that customers get a good impression of indihome services. Service Qualit, Indihome is a service which is of course required to have a good service way for customers. Can improve service when customers need it right away. Avoid anything that makes customers feel disappointed, such as repairing or checking any vulnerable network for interference. Trust, PT Telkom, which is one of the state-owned companies engaged in telecommunications and technology, has a very high role for the products being marketed. So it is possible that the relationship between customers and the company can be maintained in order to maintain trust between customers and service companies. For Further Researchers: The results of this study can be used as variable knowledge that can be used as a reference. In further research, we can add other variables such as the effect of delivery efficiency, brand image on customer loyalty because in this study, customer loyalty $(Y)$ is influenced by other factors of $31.8 \%$.

\section{REFERENCES}

Andrianto, Agus,. Pengaruh Experiental Value Terhadap Loyalitas dengan Kepuasan dan Experiental Value sebagai variabel intravening (strudi pada pelanggan D'Cost Seafood Cabang Royal Plaza Surabaya). Jurnal ilmu manajemen.

Fandy, Tjiptono. 2011. Service Management Mewujudkan Layanan Prima. Edisi 2. Yogyakarta : Andi.
Ferdinand Agusry .2014. Metode Penelitian Manajemen. BP Universitas Diponegoro.Semarang.

Ghozali, Imam. 2018. Aplikasi Analisis Multivariate dengan Program IBM SPSS 25, Semarang : adan Penerbit Universitas Diponegoro.

Groovy.id. Nama-nama ISP Brsar yang ada di Indonesia. Retrived April 122019, From https://groovy.id/nama-nama isp-besaryang-ada-di indonesia/.

Hartini, S., Mardhiyah, D. and Sukaris (2020). A conceptual framework for relationship between symbolic risk consumption with electronic word of mouth', Opcion, 36(Special Edition 26), pp. 1282-1295.

Keller.,\& Kotler. (2009) Manajemen Pemasaran, Jakarta : Erlangga.

Khadijah, Ayu,. Linda Rahma,.\& Renjana. (2019). Pengaruh Experiental Marketing dalam membangun Experiental Value Dan Relationship Quality Yang Berdampak bagi Loyalty (studi pada konsumen Happine Kitchen and Coffe, Ciganjur-Jakarta Tahun 2018). Jurnal Ilmu Sosial Ilmu Politik.

Kominfo.go.id. Pengguna Internet Indonesia Nomor Enam di Dunia . Retrived 2019, From https :// Kominfo.go.id/ content/detail/4286/ pengguna internetindonesia -nomor enam-dunia/0/ sorotan_media.

Kumparam.com. Indihome punya 5,5 Juta Pelanggan di Indonesia. Retrived 25 Maret 2019,From https :// kumparan.com /kumparantech / indihome punya- 5-5-juta- pelanggan- di indonesia 1553525984707947395.

Lupiyoadi, Rambat,. (2016). Manajemen Pemasaran Jasa :Berbasis Kompetensi Jakarta :Salemba Empat.

Maliyah, Siti,. (2015). Pengaruh Citra Merek, Kepercayaan (Trust) dan Komitmen Terhadap Loyalitas Nasabah pada PT Henan Putihrai Asset Management. Jurnal Ilmu Ilmiah Manajemen dan Bisnis. 
Pakpahan, Fisker Pandapotan, Dahliana

Kamener,. Nailal Husna,.(2016)

Pengaruh Kepercayaan, Kualitas

Pelayanan dan Kepuasan Pelanggan

Terhadap Loyalitas Pelanggan pada

Bengkel Kharisma Motor di Kota

Padang. Jurnal Ilmiah Manajemen dan Bisnis.

Putra, Eko,. (2017). Pengaruh Kepercayaan dan Kepuasan terhadap Loyalitas Mahasiswa di Sekolah Tinggi Ekonomi (STIE) Pasaman Kabupaten Pasaman Barat. Jurnal Apresiasi Ekonomi.

Sugiyono. (2017). Metode Penelitian:Kuantitatif, Kualitatif dan R\&D. Bandung: Alfabeta.

Sukaris, S., Hartini, S. and Mardhiyah,D. (2019). Increasing Electronic Word-of Mouth Activities through Self Congruity and Tourist Values',International Journal of Innovation, Creativity and Change, 9(10), pp. 162-183.

Sukaris, S., Hartini, S., \& Mardhiyah,D. (2020). The effect of perceived value by the tourists toward electronic word of mouth activity: the moderating role of conspicuous tendency. Jurnal Siasat Bisnis, 24(1), 1-17.

Trisusanti, Yelli. (2017). Pengaruh Kualitas Pelayanan dan Kepercayaan Terhadap Loyalitas Nasabah (Studi Pada Bank BNI Syariah Kantor Cabang Pekanbaru). Jurnal Administrasi Bisnis.

Wiwik, W., \& Julia, R,. (2018).Pengaruh Experiental Marketing Terhadap Loyalitas Pelanggan Taman Wisata Edukasi D'Kandang DepokJurnal Ecodemia. 